\title{
PHYSIOLOGICAL MECHANISMS OF THE LOW-INTENSITY LASER RADIATION IMPACT ON THE HIGHLY QUALIFIED ATHLETES' SPECIAL PHYSICAL PERFORMANCE
}

\author{
Bruk TM¹, Terekhov PA ${ }^{1 凶}$, Litvin FB' ${ }^{1}$, Verlin $\mathrm{SV}^{2}$
}

Smolensk State Academy of Physical Culture, Sport and Tourism, Smolensk, Russia

${ }^{2}$ Rehabilitation Center of the State School of the Olympic reserve, Bronnitsy, Moscow region, Russia

\begin{abstract}
In the context of strengthening the fight against doping and limiting the use of synthetic pharmaceuticals, the effective remedies to increase physical performance and accelerate the recovery of athletes are being sought. One of such remedies is exposure to low-level laser radiation (LLLR, LLLT). The study was aimed to investigate the physiological response of highly qualified female rowers' functional systems to the LLLR irradiation course. To monitor the body of athletes, we used laser Doppler flowmetry (LDF), mathematical analysis of heart rate, neuroenergy mapping, as well as pedagogical testing using the Concept 2 simulator. After irradiation of the neck in the projection of the carotid arteries with pulsed infrared LLLR, the blood perfusion rate increased by $38 \%(p<0.05)$ and cell oxygen utilization rate increased by $48 \%(p<0.05)$. The decrease in the hemoglobin oxygen saturation by $16 \%(p<0.05)$ was also observed. Due to LLLT, the activity of the autonomous regulation mechanism increased with an increase in the total power of the heart rate variability spectrum (TP) by $41 \%(p<0.05)$, and in highfrequency power (HF) by $73 \%(p<0.05)$. The influence of central mechanism decreased with a decrease in amplitude mode (AMo) by $71 \%(p<0.05)$, and in stress-index (SI) by $175 \%(p<0.05)$. Irradiation by LLLR promoted the efficiency of oxygen delivery to certain cerebral cortex areas with the increase of SPL. After LLLT, the speed of 2000 meters distance "passing" by athletes also increased by $3.32 \%(p>0.05)$. The discovered effects of LLLT allow one to expand the range of physiotherapeutic agents that enhance the special physical performance of athletes and accelerate recovery.
\end{abstract}

Keywords: LLLR (LLLT), heart rate variability, microcirculation, neuroenergy mapping, athletes, physical performance

Author contribution: Bruk TM — analysis of brain function (neuroenergy mapping), laser therapy; Terekhov PA — physical fitness assessment, statistical analysis of the results, manuscript writing; Litvin FB - study of microcirculation and heart rate variability, manuscript writing; Verlin SV - selection of study participants.

Compliance with ethical standards: the study was approved by the Local Ethics Committee of Smolensk State Academy of Physical Culture, Sport and Tourism (protocol № 67 dated September 9, 2018). Informed consent was obtained from all study participants.

$\square$ Correspondence should be addressed: Pavel A. Terekhov Kirova, 42 A, kv. 11.04, Smolensk, 214018; terechov_86@mail.ru

Received: 30.09.2019 Accepted: 21.10.2019 Published online: 30.10.2019

DOI: 10.24075/brsmu.2019.071

\section{ФИЗИОЛОГИЧЕСКИЕ МЕХАНИЗМЫ ВОЗДЕЙСТВИЯ НИЗКОИНТЕНСИВНОГО ЛАЗЕРНОГО ИЗЛУЧЕНИЯ НА СПЕЦИАЛЬНУЮ ФИЗИЧЕСКУЮ РАБОТОСПОСОБНОСТЬ ВЫСОКОКВАЛИФИЦИРОВАННЫХ СПОРТСМЕНОВ}

Т. М. Брук ${ }^{1}$, П. А. Терехов ${ }^{1 凶}$ Ф. Б. Литвин ${ }^{1}$, С. В. Верлин ${ }^{2}$

${ }^{1}$ Смоленская государственная академия физической культуры, спорта и туризма, Смоленск, Россия

2 Медико-восстановительный центр Государственного училища олимпийского резерва, Бронницы, Московская область, Россия

\begin{abstract}
В условиях ужесточения борьбы с допингом и ограничения использования синтетических фармпрепаратов ведется поиск эффективных средств для повышения физической работоспособности и ускорения восстановления спортсменов. Одним из таких средств является воздействие низкоинтенсивным лазерным излучением (НИЛИ). Целью настоящего исследования было изучение физиологического ответа функциональных систем высококвалифицированных гребцов-академистов (женщины) на курсовое воздействие НИЛИ. Для наблюдения за организмом спортсменок использовали лазерную допплеровскую флоуметрию (ЛДФ), математический анализ сердечного ритма, нейроэнергокартирование, а также педагогическое тестирование с использованием тренажера Concept 2. После освечивания шеи в области проекции сонных артерий импульсным инфракрасным НИЛИ наблюдали повышение показателя перфузии крови на 38\% ( $<$ < 0,05), показателя утилизации кислорода клетками на 48\% ( $<<0,05)$, а также снижение показателя сатурации гемоглобина кислородом на 16\% ( $<$ 0,05). В результате применения НИЛИ происходило повышение активности автономного механизма регуляции с ростом мощности спектра колебаний ритма сердца (ТP) на 41\% (p < 0,05), мощности высокочастотных колебаний (НF) - на $73 \%$ ( $<$ 0,05), росло влияние центрального механизма со снижением амплитуды моды (АМо) на $71 \%(p<0,05)$, индекса напряжения (ИН) - на 175\% ( $>$ < 0,05). Воздействие НИЛИ способствовало повышению эффективности доставки кислорода в отдельные области коры больших полушарий с ростом уровня постоянных потенциалов (УПП). Благодаря воздействию НИЛИ на 3,32\% (p > 0,05) выросла скорость «прохождения» спортсменками дистанции 2000 м. Обнаруженные эффекты применения НИЛИ позволяют расширить спектр физиотерапевтических средств, способствующих повышению специальной физической работоспособности спортсменов и ускорению восстановления.
\end{abstract}

Ключевые слова: НИЛИ, вариабельность сердечного ритма, микроциркуляция, нейроэнергокартирование, спортсмены, работоспособность

Информация о вкладе авторов: Т. М. Брук - анализ функционального состояния мозга (нейроэнергокартирование), проведение лазерных процедур; П. А. Терехов - оценка специальной физической подготовленности, статистическая обработка результатов, подготовка рукописи; Ф. Б. Литвин изучение процессов микрогемоциркуляции, вариабельности сердечного ритма, подготовка рукописи; С. В. Верлин - отбор участников исследования.

Соблюдение этических стандартов: исследование одобрено этическим комитетом ФГБОУ ВО «СГАФКСТ» (протокол № 67 от 9 сентября 2018 г.). Все спортсменки подписали добровольное информированное согласие на участие в исследовании.

$\bowtie$ Для корреспонденции: Павел Александрович Терехов ул. Кирова, д. 42 А, кв. 11.04, г. Смоленск, 214018; terechov_86@mail.ru Статья получена: 30.09.2019 Статья принята к печати: 21.10.2019 Опубликована онлайн: 30.10.2019 DOI: $10.24075 /$ vrgmu.2019.071

To achieve record levels, highly qualified athletes work at the limit of the body's functional capabilities, which often lead to homeostasis impairment. One of the ways to preserve homeostasis is to expand the adaptive boundaries of organs and systems that provide the response to training and competitive physical loads, which ensures the achievement of an adaptive result [1]. 
According to literature data, as a result of low-level laser radiation (LLLR) absorption, energy is transformed into various biological reactions, which trigger the processes of self-regulation and self-healing of impaired homeostasis [2-5]. In particular, under the influence of LLLT, antioxidant defense enzymes are activated, cell metabolism is enhanced, biomembranes are stabilized. The effect of LLLR on the elasticity of erythrocyte membranes facilitates the red blood cells penetration into the capillaries of the microvascular bed, and the stimulation of the energy metabolism aerobic phase involving the incompletely deoxidized glycolysis metabolites and lipid oxidation products as well as the indirect membrane mechanism, leads to oxygen saturation of the venous blood and improves microcirculation [6]. At the same time, the influence of LLLT on microcirculatorytissue relations remains understudied [7].

Laser therapy is an essential component of modern biomedical support of the elite sport at almost all stages of athletes' training. Comprehensive monitoring of the athlet's body using a complex of informative and reproducible methods for rapid assessment of body state (biochemical and hematological indicators, laser Doppler flowmetry (LDF) data, heart rate variability (HRV), neuroenergy mapping (NEM) data, etc.) allows one to correct the athlete's homeostasis for adequate formation of fatigue not going beyond the pathology side and for acceleration of the recovery processes.

Researchers revealed the ability of LLLT to improve the physical performance of athletes of various qualifications involved in different sports. LLLR irradiation of biologically active points leaded to an increase in the aerobic performance indicator in $80 \%$ of football players with a subsequent increase in the amount of mechanical work performed [8]. A significant increase in the absolute and relative values of PWC170 after LLLT was obtained in athletes of cyclic sports. Short-term exposure to LLLR did not cause significant changes in the biochemical composition of the blood, but increased the activity of parasympathetic influences on the heart rhythm $[9,10]$. The humoral-hormonal status of the athletes' body changed due to LLLT. In particular, an increase in the concentration of beta-endorphin, glucocorticoids, triiodothyronine, thyroxine in game sports athletes and crosscountry skiers was revealed [11, 12].

The systemic mechanisms that provide the effects of laser stimulation as a part of the complex training program of hockey players are described. Positive structural and functional changes in the body of hockey players and swimmers lead to a marked improvement of the physical fitness $[13,14]$.

The study was aimed to investigate the physiological response of highly qualified female rowers' functional systems to the LLLR irradiation course in the special preparatory period of the annual cycle of sports training. The objectives of the study were as follows: assessment of the LLLT effect on the microcirculation system, detection of the heart rate regulation changes, investigation of the effect on the metabolic activity of the cerebral cortex neurons, evaluation of the highly qualified athletes' physical performance.

\section{METHODS}

The study was conducted in October 2018. Twenty four highly qualified female rowers studying at the State School of the Olympic reserve (Bronnitsy, Moscow region) participated in the study which was carried out at the training center.

The participants were divided into two groups: treatment group (TG) and control group (CG). The treatment group included 12 athletes. Inclusion criteria: Master of Sports (MS) qualification level, membership in the Moscow Region combined team. Exclusion criteria: low qualification of athletes, the acute phase of the disease. The control group included 12 athletes (MS) not qualified for the combined team. Representatives of both groups used the single training program.

The study included two phases. At the first phase of the study, we evaluated the functional state of individual body systems and the physical fitness of the TG and CG athletes before LLLT. Then, the athletes of both groups in their weekly training cycle performed a special training program to prepare for the competition season.

The TG athletes were exposed to LLLT during 7 days in the morning before training. Their necks were irradiated neck symmetrically on both sides in the region of the carotid triangle using Uzor-A-2K 2-channel therapeutic laser unit (Voskhod; Russia). The laser radiation wavelength was $0.89 \pm$ $0.02 \mu \mathrm{m}$; pulse mode; pulse repetition frequency $1500 \mathrm{~Hz}$; 10 minute exposure time. The CG athletes were through the fake LLLT without turning on the emitting heads of the Uzor-A-2K unit. After laser therapy the studied indices were registered again.

The athletes' heart rate variability (HRV) was evaluated using the Varicard 2.51 complex (Ramena; Russia). The recording of cardiointervalogram lasting 5 minutes was carried out using the standard method in a sitting position. The following HRV parameters were evaluated: heart rate $(H R)$, indicators characterizing the activity of autonomous (total power of the heart rate variability spectrum (TP), high-frequency power (HF) and central (low-frequency power (LF), very-low-frequency power (VLF), amplitude mode (AMo) regulatory mechanisms, indicator of the prevalence of central regulatory mechanisms over autonomous (stress-index, SI)

The LAKK-M (Lazma; Russia) multifunctional laser diagnostic system was used as a recording instrument for studying microcirculation. After that the microcirculation parameter (PM) was analyzed in perfusion units (PU). The timefrequency analysis of blood flow oscillations was performed using the wavelet analysis LDF3.0.2.384 software (Lazma; Russia). The active mechanism contribution to the formation of vascular tone was estimated by the amplitude of sympathetic (As), myogenic (Am) and endothelial (Ae) oscillations (PU). The contribution of passive mechanism was estimated by the amplitude of respiratory ( $\mathrm{Ar}$ ) and cardiac (Ac) oscillations (PU). The optical tissue oximetry method was used for evaluation of blood oxygen saturation level $\left(\mathrm{SO}_{2}, \%\right)$ and specific oxygen consumption rate $(U$, p.d.u.). The steady potentials level (SPL) parameter was used for assessment of the brain tissue metabolic activity in the frontal, parietal, occipital, right and left temporal lobes.

For topographic mapping of brain electrical activity the 5-channel Neuro-KM complex was used (STATOKIN; Russia) according to standard method [15]. The time of 2000 meter distance "passing" using the Concept 2 Model D (PM5; China) rowing simulator was the indicator of special physical fitness. The test was performed indoors, in the gym with constant temperature and illumination intensity.

Statistical analysis of the results was carried out using the IBM SPSS Statistics 19 software for Windows (StatSoft, Inc.; USA). The Mann-Whitney U-test was used to compare the studied indicators in the TG and $C G$ athletes. To compare the indicators in TG athletes and $C G$ athletes who experienced the imaginary effect of LLLT, as well as with the indicators of athletes after laser therapy, the Wilcoxon signed-rank test was used. The differences were considered significant at $p<0.05$. 


\section{RESULTS}

Percutaneous laser stimulation combined with standard training loads promotes the expansion of the body functional capabilities at various organization levels (from cellular to systemic). We studied the dynamics of the processes that occurred in the microvascular beds after the course of LLLT.

In the TG athletes, the perfusion level significantly increased by $38 \%$ compared to baseline $(p<0.05)$. At the same time, in the CG athletes the microcirculation parameter increased by $5 \%(p>0.05)$ (Table 1$)$. The 14\% decrease in $\mathrm{SO}_{2}$ in the microvascular beds together with a tendency to $\mathrm{SO}_{2}$ increase by $2 \%$ in the CG was the evidence of oxygen metabolism biostimulation in the TG athletes due to LLLT $(p<0.05)$. A significant increase by $49 \%$ in the estimated rate of oxygen utilization by tissues was an indicator of oxygen diffusion from blood into the tissue $(p<0.05)$. In the CG athletes the same indicator demonstrated almost no growth $(1 \%, p>0.05)$.

In our study, the myocyte tone decreased by $53 \%(p<0.05)$ in the TG athletes, thereby increasing the lumen of the microvascular bed vessels. In addition, arterioles widened the lumen due to the decrease in the activity of the autonomic nervous system sympathetic nerves, the ends of which innervate smooth muscle cells of the blood vessel wall middle layer. According to the wavelet analysis, the indicator of sympathetic tone was reduced by $40 \%(p<0.05)$. As a result of LLLT, the throughput of the microvascular bed exchange link increased due to vasodilation of microvessels of various diameters.

At the autonomic nervous system (ANS) level, the course of LLLT reduced the activity of the sympathetic region, while increasing the effect of the ANS parasympathetic region on the heart, which provided trophotropic recovery effect (Table 2). As a result, stress-index reduced by $174 \%$, AMo reduced by $48 \%$ $(p<0.05)$. The TP index significantly increased by $41 \%$. Certain spectrum parameters increased as well (LF by $121 \%$ and HF by $73 \%, p<0.05)$. Noteworthy is the $75 \%$ increase in the VLF index, which reflects the function of cortical-humoral centers.

Without physiotherapy, during training in the CG athletes, sympathetic influences maintained high activity with a tendency to reduce the effect of the vagus nerve on the heart rhythm. High sympathoadrenal system activity promoted energy deficiency. In TG athletes, during the recovery period between training sessions, tissue anabolism increased due to LLLT, thus providing high functional readiness of the body for training activities. At the same time, increased catabolism maintained in the CG athletes caused the fatigue accumulation due to the under-recovery of the body after another training session.

LLLT indirectly stimulates functional adaptive changes in the cerebral cortex neurons. After the course of LLLT the TG athletes demonstrated enchanced metabolic activity of brain tissue in the studied areas, which was evidenced by the growth of steady potential level (SPL) value. Compared to baseline

Table 1. Blood microcirculation in highly qualified female rowers at various stages of the study $(\mathrm{M} \pm m)$

\begin{tabular}{|c|c|c|c|c|c|}
\hline \multirow{2}{*}{ № } & \multirow{2}{*}{ Index } & \multirow{2}{*}{ Group } & \multicolumn{2}{|c|}{ Study phase } & \multirow{2}{*}{$p<0.05$} \\
\hline & & & 1 & II & \\
\hline \multirow{3}{*}{1} & \multirow{3}{*}{ PM, PU } & $\mathrm{TG}$ & $12.92 \pm 1.61$ & $17.86 \pm 2.05$ & * \\
\hline & & $C G$ & $11.50 \pm 1.34$ & $12.07 \pm 1.80$ & \\
\hline & & $p$ & $>0.05$ & ${ }^{* *}<0.05$ & \\
\hline \multirow{3}{*}{2} & \multirow{3}{*}{$\mathrm{SO}_{2} \cdot \%$} & $\mathrm{TG}$ & $80.2 \pm 4.04$ & $69.1 \pm 3.72$ & * \\
\hline & & $C G$ & $81.2 \pm 4.56$ & $82.9 \pm 5.17$ & \\
\hline & & $p$ & $>0.05$ & ${ }^{* *}<0.05$ & \\
\hline \multirow{3}{*}{3} & \multirow{3}{*}{ U, p.d.u. } & TG & $1.87 \pm 0.10$ & $2.79 \pm 0.16$ & * \\
\hline & & CG & $1.68 \pm 0.08$ & $1.70 \pm 0.12$ & \\
\hline & & $p$ & $>0.05$ & ${ }^{* *}<0.05$ & \\
\hline \multirow{3}{*}{4} & \multirow{3}{*}{$A c, P U$} & TG & $13.25 \pm 1.84$ & $18.01 \pm 2.59$ & * \\
\hline & & $C G$ & $15.38 \pm 2.34$ & $13.79 \pm 1.83$ & \\
\hline & & $p$ & $>0.05$ & $>0.05$ & \\
\hline \multirow{3}{*}{5} & \multirow{3}{*}{$\mathrm{Ar}, \mathrm{PU}$} & $\mathrm{TG}$ & $20.06 \pm 2.93$ & $22.57 \pm 3.12$ & \\
\hline & & CG & $17.84 \pm 2.50$ & $23.19 \pm 4.01$ & \\
\hline & & $p$ & $>0.05$ & $>0.05$ & \\
\hline \multirow{3}{*}{6} & \multirow{3}{*}{ Am, PU } & $\mathrm{TG}$ & $25.70 \pm 3.10$ & $39.41 \pm 4.80$ & * \\
\hline & & CG & $26.24 \pm 4.42$ & $27.11 \pm 3.86$ & \\
\hline & & $p$ & $>0.05$ & ${ }^{* *}<0.05$ & \\
\hline \multirow{3}{*}{7} & \multirow{3}{*}{ As, PU } & $\mathrm{TG}$ & $31.93 \pm 2.72$ & $44.69 \pm 4.90$ & * \\
\hline & & CG & $29.13 \pm 3.15$ & $30.42 \pm 3.16$ & \\
\hline & & $p$ & $>0.05$ & ${ }^{* *}<0.05$ & \\
\hline \multirow{3}{*}{8} & \multirow{3}{*}{$\mathrm{Ae}, \mathrm{PU}$} & $\mathrm{TG}$ & $35.78 \pm 4.96$ & $58.00 \pm 5.70$ & * \\
\hline & & $C G$ & $30.85 \pm 3.75$ & $33.55 \pm 4.28$ & \\
\hline & & $p$ & $>0.05$ & ${ }^{* *}<0.05$ & \\
\hline
\end{tabular}

Note: PM — microcirculation parameter; $\mathrm{SO}_{2}$ — blood oxygen saturation in skin tissue; U — oxygen consumption; Ac — cardiac PM oscillations; Ar — respiratory PM oscillations; Am — myogenic PM oscillations; As — sympathetic PM oscillations; Ae — endothelial PM oscillations; ${ }^{*}$ — differences between groups; * — intragroup differences; $p<0.05$. 
(Table 3), there was an increase in the SCP indicator by $94 \%$ in the frontal lobe, by $109 \%$ in the parietal lobe, by $33 \%$ in the occipital lobe and $29 \%$ in the left temporal lobe $(p<0.05)$.

The steady potential values after LLLT were distributed according to the dome-shaped curve principle (Table 3). In the CG athletes, maximum SPL values were registered in occipital $(\mathrm{Oz})$ and left temporal (Ts) lobes. Thus, the dome-shaped distribution of energy consumption by the brain was violated, i.e. some deformation occured.

In the CG rowers, the SPL value tended to increase during the study, the differences were not significant.

Thus, the energy metabolism of neurons in the studied regions of cerebral cortex increased after the course of LLLT.

For correct assessment of the effectiveness of the LLLT use as a remedy for recovery it is advisable to evaluate the physical fitness level. In our study we evaluated the physical fitness level using testing with the Concept 2 rowing simulator. The time needed by the highly qualified female rowers to "pass" the 2000 meters distance at various phases of the study is presented in Table 4. At the first phase (baseline) no significant differences between two groups were revealed. The CG athletes "passed" the distance in $456.55 \pm 3.55 \mathrm{~s}$, and the TG rowers "passed" the distance in $454.07 \pm 2.43 \mathrm{~s}(p>0.05)$.

The course of LLLT stimulated the body of the TG athletes increasing the speed of "passing" the 2000 meter distance up to $435.63 \pm 2.34 \mathrm{~s}$, which was $3.32 \%$ less than baseline $(p<0.01)$. In the CG rowers, the time needed for "passing" the distance remained almost unchanged (453.02 $\pm 3.34 \mathrm{~s})$ $(p>0.05)$. Thus, combined with the standard training process, the course of LLLT leaded to an increase in the special physical performance of female rowers during the special preparatory period of the sports training annual cycle.

\section{DISCUSSION}

The analysis of the obtained data demonstrated that the course of LLLT improved the microhemocirculation system function. We detected a significant perfusion increase, indicating an enchancement of metabolic activity at the cellular and tissue levels. An increase in the microcirculation intensity is associated with vasodilation, regulation in the microcirculation system is provided by external and internal mechanisms [16-18].

Of the internal mechanisms, the maximum contribution to the increase of the microvascular bed vessels capacity is provided by the endothelial component. Endotheliocytes take part in the formation of the vasodilation response which leads to the reduction of the microvascular tone by $62 \%(p<0.05)$. The trigger stimulus arising in response to LLLT is the release of vasodilator, nitric oxide $(\mathrm{NO})$ by $\mathrm{Ca}^{2+}$-dependent endothelial cells, which is a precursor of the endothelium-derived relaxing factor (EDRF) [19]. Myogenic vasodilation is due to a decrease in the smooth muscle cells tone of the vascular wall.

In smooth muscle cells, LLLT leads to an increase in the level of intracellular CAMP in the cytosol, leading to activation of calcium ATPase, a decrease in calcium ions level in the cytoplasm, and relaxation of vascular smooth muscle cells [20].

The pronounced effect of laser photostimulation is associated with the effect of low-intensity radiation on

Table 2. Heart rate variability in highly qualified female rowers at various stages of the study $(\mathrm{M} \pm m)$

\begin{tabular}{|c|c|c|c|c|c|}
\hline \multirow{2}{*}{ № } & \multirow{2}{*}{ Index } & \multirow{2}{*}{ Group } & \multicolumn{2}{|c|}{ Study phase } & \multirow{2}{*}{$p<0.05$} \\
\hline & & & I & ॥ & \\
\hline \multirow{3}{*}{1} & \multirow{3}{*}{$\mathrm{HR}, \mathrm{bpm}$} & TG & $75.66 \pm 3.20$ & $66.94 \pm 2.04$ & * \\
\hline & & $\mathrm{CG}$ & $77.17 \pm 3.18$ & $75.67 \pm 3.25$ & \\
\hline & & $p$ & $>0.05$ & ${ }^{* *}<0.05$ & \\
\hline \multirow{3}{*}{2} & \multirow{3}{*}{ AMo, \% } & TG & $40.10 \pm 3.55$ & $26.52 \pm 2.41$ & * \\
\hline & & $C G$ & $37.92 \pm 0.91$ & $38.55 \pm 0.88$ & \\
\hline & & $p$ & $>0.05$ & ${ }^{* *}<0.05$ & \\
\hline \multirow{3}{*}{3} & \multirow{3}{*}{ SI, p.d.u. } & TG & $167.02 \pm 19.53$ & $60.73 \pm 6.38$ & * \\
\hline & & $C G$ & $126.27 \pm 13.87$ & $123.94 \pm 13.64$ & \\
\hline & & $p$ & $>0.05$ & ${ }^{* *}<0.05$ & \\
\hline \multirow{3}{*}{4} & \multirow{3}{*}{$\mathrm{TP}, \mathrm{ms}^{2}$} & TG & $3793.11 \pm 522.24$ & $5340.14 \pm 701.02^{*}$ & * \\
\hline & & $\mathrm{CG}$ & $1564.17 \pm 209.46$ & $1598.62 \pm 213.95$ & \\
\hline & & $p$ & ${ }^{* *}<0.05$ & ${ }^{* *}<0.05$ & \\
\hline \multirow{3}{*}{5} & \multirow{3}{*}{$\mathrm{HF}, \mathrm{ms}^{2}$} & TG & $967.95 \pm 130.74$ & $1671.85 \pm 175.12$ & * \\
\hline & & $\mathrm{CG}$ & $877.50 \pm 120.29$ & $581.31 \pm 70.37$ & \\
\hline & & $p$ & $>0.05$ & ${ }^{* *}<0.05$ & \\
\hline \multirow{3}{*}{6} & \multirow{3}{*}{$\mathrm{LF}, \mathrm{ms}^{2}$} & TG & $889.65 \pm 153.29$ & $1965.54 \pm 233.56$ & * \\
\hline & & $C G$ & $473.67 \pm 50.07$ & $477.00 \pm 50.29$ & \\
\hline & & $p$ & $>0.05$ & ${ }^{* *}<0.05$ & \\
\hline \multirow{3}{*}{7} & \multirow{3}{*}{$\mathrm{VLF}, \mathrm{ms}^{2}$} & TG & $967.75 \pm 150.62$ & $1693.76 \pm 195.17$ & * \\
\hline & & $C G$ & $519.50 \pm 79.60$ & $426.57 \pm 61.58$ & \\
\hline & & $p$ & $>0.05$ & ${ }^{* *}<0.05$ & \\
\hline
\end{tabular}

Note: HR — heart rate; AMo — amplitude mode; SI — stress index; TP — total power of the heart rate variability spectrum; HF — high-frequency power; LF — lowfrequency power; VLF — very-low-frequency power; ${ }^{* *}$ — differences between groups; ${ }^{\star}$ — intragroup differences; $p<0.05$. 
metabolism. Oxidation of energy materials (glucose, pyruvate, lactate) increases, leading to improvement of microcirculation and oxygen utilization in tissues [21]. According to the data obtained, the mixed blood hemoglobin saturation with oxygen of the microvascular bed decreases, the specific oxygen consumption of tissues increases, which facilitate metabolism and provide energy production in the form of ATP in the cells [22]. An increase in the cells functional activity occurs primarily due to calcium-dependent increase in the redox potential of mitochondria, an increase in their functional activity, and ATP synthesis [23-26]. In mitochondria, LLLT accelerates the electron transfer along the respiratory pathway [26].

According to PK Anokhin's functional systems theory, structural and functional components of different level and localization are involved in the implementation of the adaptive effect by the organism. Local improvement of homeostasis at the tissue microcirculation level is a component of the vegetative balance restructuring at the system level [27]. Under the influence of high-intensity physical activity, the optimal ratio between the sympathetic and parasympathetic ANS links is violated in favor of the predominance of sympathicotonia, reflecting the imbalance of the reciprocal regulatory effects of the ANS on the athlete's cardiac system. In such conditions, a pronounced tension of the compensatory mechanisms of the athlete's cardiovascular system is observed, which is associated with distress [28].

It was found that LLLT changes the activity of the neural pathways involved in the regulation of cardiac activity. Some authors note that LLLT activates the calcium-dependent mechanisms [29]. Calcium is an intracellular mediator of a number of hormones, primarily mediators of CNS and ANS [30], suggesting the involvement of laser-induced effects in neurohumoral regulation. At the end of the laser therapy course, the activity of the ANS sympathetic division decreases, the contribution of the parasympathetic division increases, and the total intensity of regulatory processes decreases. In general, LLLT promotes the deployment of trophotropic processes aimed at preserving energy and plastic resources.

It is well known that sports activity gives results only when the athlete's skill is refined to automatism, that is, with minimal participation from the central regulatory systems. A system with relatively autonomous links, due to the independence of its elements, is more flexible, which facilitates its adaptation to changing environmental conditions, including adaptation to sports activity [31]. An increase in the number of the sinus node degrees of freedom helps the body to achieve a functional optimum to cope the load. As a result, SI reduces by $174 \%(p<0.05)$. The spectral parameters dynamics indicates a transition to a higher level of adaptive capabilities ensuring the athlete's body resistance to training loads. Thus, the growth rate of the activity of the autonomous heart rhythm control (HF) pathway increases by $73 \%$, and of the central (LF) by $121 \%$. At the same time, the contribution of cortical-humoral control centers (VLF) is enhanced by $75 \%$ against the background of bradycardia. Such a spectrogram reflects the high functional capabilities of the athlete's body [32].

An increase in the functional reserve of the body after a course of LLLT has been noted earlier [33-34]. Laser radiation regulates restoration of the vegetative balance and restrains the activity of the sympathoadrenal system [35]. The evidence was obtained of the relationship between the increased relative power of a heart rhythm spectrum in the VLF frequency range with a change in the frequency and time parameters of the brain rhythmic activity [36]. Rhythmic activity was detected in the frontal, parietal and occipital lobes of the brain.

Table 3. Steady potentials level $(\mathrm{mV})$ in certain areas of cerebral cortex of highly qualified female rowers at various stages of the study $(\mathrm{M} \pm m$ )

\begin{tabular}{|c|c|c|c|c|c|}
\hline \multirow{2}{*}{ № } & \multirow{2}{*}{ Index } & \multirow{2}{*}{ Group } & \multicolumn{2}{|c|}{ Study phase } & \multirow{2}{*}{$p<0.05$} \\
\hline & & & I & II & \\
\hline \multirow{3}{*}{1} & \multirow{3}{*}{ Frontal lobe (Fz) } & TG & $7.129 \pm 0.384$ & $13.851 \pm 0.531$ & * \\
\hline & & $\mathrm{CG}$ & $5.214 \pm 0.312$ & $5.915 \pm 0.334$ & \\
\hline & & $p$ & $>0.05$ & ${ }^{* *}<0.05$ & \\
\hline \multirow{3}{*}{2} & \multirow{3}{*}{ Parietal lobe (Cz) } & TG & $7.277 \pm 0.390$ & $15.239 \pm 0.745$ & * \\
\hline & & $C G$ & $7.315 \pm 0.411$ & $7.854 \pm 0.425$ & \\
\hline & & $p$ & ${ }^{* *}<0.05$ & $>0.05$ & \\
\hline \multirow{3}{*}{3} & \multirow{3}{*}{ Occipital lobe (Oz) } & TG & $9.724 \pm 0.404$ & $12.954 \pm 0.525$ & * \\
\hline & & $C G$ & $8.057 \pm 0.354$ & $8.948 \pm 0.477$ & \\
\hline & & $p$ & $>0.05$ & $>0.05$ & \\
\hline \multirow{3}{*}{4} & \multirow{3}{*}{ Left temporal lobe (Ts) } & TG & $10.121 \pm 0.334$ & $13.063 \pm 0.526$ & * \\
\hline & & CG & $10.289 \pm 0.351$ & $11.973 \pm 0.382$ & \\
\hline & & $p$ & $>0.05$ & $>0.05$ & \\
\hline
\end{tabular}

Note: TG — treatment group; CG — control group; ${ }^{*}$ — differences between groups; ${ }^{*}$ — intragroup differences; $p<0.05$.

Table 4. Time of 2000 meter distance "passing" using the Concept 2 simulator by highly qualified female rowers at various stages of the study ( $\mathrm{M} \pm m$ )

\begin{tabular}{|c|c|c|c|c|c|}
\hline \multirow{2}{*}{ № } & \multirow{2}{*}{ Index } & \multirow{2}{*}{ Group } & \multicolumn{2}{|c|}{ Study phase } & \multirow{2}{*}{$p<0.05$} \\
\hline & & & I & II & \\
\hline \multirow{3}{*}{1} & \multirow{3}{*}{ Time of 2000 meter distance "passing" using the Concept 2 simulator, s } & $\mathrm{TG}$ & $454.07 \pm 2.43$ & $435.63 \pm 2.34$ & * \\
\hline & & CG & $456.55 \pm 3.55$ & $453.02 \pm 3.34$ & \\
\hline & & $p$ & $>0.05$ & ${ }^{* *}<0.01$ & \\
\hline
\end{tabular}

Note: TG — treatment group; CG — control group; ${ }^{\star \star}$ — differences between groups; ${ }^{*}$ — intragroup differences; $p<0.05$. 
Some researchers suggest that normal energy exchange is mainly characterized by the dome-shaped curve, in which the maximum potential values are recorded in the central lead $(\mathrm{Cz})$ and gradually decrease to the periphery [37]. Obviously, an SPL shift in the occipital and left temporal lobes may be associated with an increase in the functional activity of nonspecific reticularlimbic-cortical neural pathways [38].

An imbalance of regulatory influences from the higher nervous activity, depending on the brain and its cortex, leads to a violation of the speed of conditioned reflex reactions, a violation of the interaction between the first and second signaling systems, accompanied by emotional and behavioral deviations [39]. However, the adaptation mechanisms of athlete's cortical neurons under the influence of extremely high physical activity remain understudied. The results of our study on the metabolic activity of neurons in certain areas of the cerebral cortex after the course of LLLT demonstrate an improvement in the steady potential level by 1.3-2 times.

The structural and functional adaptation changes in the body arising under the influence of LLLT promote the improvement of physical performance and physical fitness of highly qualified rowers. The interaction of low-energy laser radiation with the body allows one to create a highly effective method of using laser therapeutic units in a set of remedies for improvement of special physical performance, physical fitness and overall athletic performance of athletes [40].

\section{CONCLUSION}

Our study results demonstrated that exposure to LLLR improved the functional state of the athlete's body and increased the effectiveness of sports training at the preparatory stage. The systemic response to LLLT was associated with perfusion increase in the exchange link of microvascular bed, facilitation of the diffusion of oxygen from blood into tissues and an increase in the efficiency of oxygen consumption in the cell. To a large extent, additional influx of blood from the main vessels ensured the microcirculation increase. After the course of LLLT, the increase of metabolic activity of neurons in certain areas of the cerebral cortex was observed. Thus, the adaptive stability of the body increase due to laser therapy, its functional capabilities expand, which helps to improve the athletes' special physical performance and accelerate the recovery process.

\section{References}

1. Anokhin PK. Printsipial'nye voprosy obshchey teorii funktsional'nykh sistem. Printsipy sistemnoy organizatsii funktsiy. M.: Nauka", 1973, p. 5-61.

2. Kuznetsova TN, Pavlov SE. Metodika primeneniya fizioterapevticheskikh sredstv (nizkoenergeticheskikh IK-lazerov) $v$ trenirovochnom protsesse plovtsov. Metodicheskaya razrabotka dlya prepodavateley, aspirantov i studentov RGAFK. M.: RGAFK, 1997; 52 p.

3. Dorovskikh VA, Borodin EA, Borodina GP et al. Vliyanie nizkoenergeticheskikh lazerov na svobodnoradikal'noe okislenie glyukozo-6-fosfat degidrogenazy i katalazy eritrotsitov. V sbornike: Materialy Mezhdunarodnogo kongressa "Lazer i zdorov'e-99", Moskva, 1999; 435-6.

4. Kozel Al, Popov GK. Mekhanizm deystviya lazernogo oblucheniya na tkanevom i kletochnom urovne. Vestnik RAMN. 2000; 2: 41-3.

5. Ulashchik VS. Analiz mekhanizmov pervichnogo deystviya nizkointensivnogo lazernogo izlucheniya na organizm. Zdravookhranenie (Minsk). 2016; 6: 41-51.

6. Potemkin LA. Mediko-biologicheskoe obespechenie i kvantovaya meditsina sporta vysshikh dostizheniy. M.: Izd-vo ZAO "MILTAPKP GIT", 2001; 135 p.

7. Krupatkin Al, Sidorov W. Funktsional'naya diagnostika sostoyaniya mikrotsirkulyatorno-tkanevykh sistem: Kolebaniya, informatsiya, nelineynost'. Rukovodstvo dlya vrachey. M.: LIBROKOM, 2014 $498 \mathrm{p}$.

8. Bogoslova TV. Vliyanie nizkointensivnogo lazernogo izlucheniya na fizicheskuyu rabotosposobnost' studentov instituta fizicheskoy kul'tury [dissertatsiya]. Yaroslavl', 2004.

9. Osipova NV. Sravnitel'naya kharakteristika vliyaniya nizkointensivnogo lazernogo izlucheniya na uroven' fizicheskoy rabotosposobnosti studentov razlichnykh spetsializatsiy sportivnogo vuza [dissertatsiya]. SPb., 2008.

10. Prokopyuk ZN. Ustoychivost' organizma sportsmenov k gipoksi i ee korrektsiya nizkointensivnym lazernym vozdeystviem [dissertatsiya]. Smolensk, 2010.

11. Lifke MV. Dinamika gormonal'nogo statusa sportsmenov razlichnoy kvalifikatsii, vypolnyayushchikh fizicheskuyu nagruzku umerennoy moshchnosti na fone lazernogo vozdeystviya [dissertatsiya]. Kursk, 2009

12. Volkova AA. Vliyanie nizkointensivnogo lazernogo izlucheniya na funktsional'noe sostoyanie organizma lyzhnikov-gonshchikov, [dissertatsiya]. Smolensk, 2011.

13. Pavlov SE., Razumov AN, Pavlov AS. Laser stimulation in medical and biological provision of qualified sportsmen training. Moscow: Publishing house "Sport", 2017; 536 p.

14. Pavlov SE, Pavlov AS, Petrov AA. Osobennosti dinamik chrednegruppovykh pokazateley dispersionnykh kharakteristik funktsionirovaniya miokarda khokkeistov, ispol'zovavshikh v predstartovoy podgotovke metod lazernoy stimulyatsii sportivnoy rabotosposobnosti. V sbornike: Olimpiyskiy byulleten' № 15, sost. Mel'nikova NYu, Treskin AV, Leonteva NS, Nikiforova AYu; M.: Izdvo ZAO "Olimpiyskaya panorama", 2014; 247-51.

15. Fokin VF, Ponomareva NV, Kuntsevich Gl. Elektrofiziologicheskie korrelyaty skorosti dvizheniya krovi po sredney mozgovoy arteril zdorovogo cheloveka. Vestnik RAMN. 2013; (10): 57-60.

16. Bollinger $A$. Is high-frequency flux motion due to respiration or to vasomotion activity? In: A. Bollinger et al. Vasomotion and flow motion. Prog Appl Microcirculation. Basel, Karger. 1993; 20: 52-8.

17. Fagrell B. Problems using laser Doppler on the skin in clinica practice. Laser Doppler.- London - Los Angeles - Nicosia: Med Orion Rublishing Company. 1994; 49-54.

18. Fedorovich AA. VEB-kapillyaroskopiya - novye vozmozhnosti monitorirovaniya kapillyarnogo krovotoka $\vee$ kozhe cheloveka. $V$ sbornike: Materialy XII mezhdunarodnoy nauchnoy konferentsii "Mikrotsirkulyatsiya i gemoreologiya"; 01-03 iyulya 2019 g.; Yaroslavl': Kantsler 2019: 11.

19. Murrey RK et al. Harper's Biochemistry. Appleton \& Lange, 1996; $700 \mathrm{p}$.

20. Daniolos A, Lerner AB, Lerner MR. Action of light on frog pigment cells in culture. Rigment Cell Res. 1990; 3(1): 38-43.

21. Tambovskiy AN, Sidorenko TA. Nekotorye rezul'taty primeneniya vnetrenirovochnogo sredstva $v$ protsesse podgotovki grebtsov. Uchenye zapiski universiteta imeni P.F. Lesgafta. 2015; 5 (123): $182-85$.

22. Karu TY. Pervichnye i vtorichnye kletochnye mekhanizmy lazernoy terapii. V knige: Moskvin SV, Buylin VA, redaktory. Nizkointensivnaya lazernaya terapiya. M.: Tekhnika, 2000; p. 71-94.

23. Maltsev AP. Mekhanizmy deystviya lazernogo izlucheniya na prokarioticheskie kletki. Mezhdunarodnyy studencheskiy nauchnyy vestnik. 2016; (6): 23.

24. Filippin L, Magalhães PJ, Di Benedetto G et al. Stable interactions between mitochondria and endoplasmic reticulum allow rapid accumulation of calcium in a subpopulation of mitochondria. $J$ Biol Chem. 2003; 278 (40): 39224-34. 
25. Schaffer M, Sroka R, Fuchs $C$ et al. Biomodulative effects induced by $805 \mathrm{~nm}$ laser light irradiation of normal and tumor cells. Journal of Photochemistry and Photobiology B: Biology. 1997; 40 (3) 253-57.

26. Eliseenko VI. Mekhanizmy vzaimodeystviya nizkoenergeticheskogo lazernogo izlucheniya IK-spektra s biologicheskimi tkanyami $\mathrm{V}$ sbornike: Lazery i aeroiony v meditsine pod red. Evstigneeva AR, Kaplana MA; Kaluga-Obninsk, 1997: 71-2.

27. Krupatkin Al. Neinvazivnaya otsenka tkanevogo dykhaniya u cheloveka $s$ ispol'zovaniem veyvlet-analiza kolebaniy saturatsii krovi kislorodom i krovotoka v mikrososudakh kozhi. Fiziologiya cheloveka. 2012; 38 (4): 67-73.

28. Gavrilova EA, Larintseva OS. Faktory riska vnezapnoy serdechnoy smerti sportsmenov na raznykh etapakh sportivnoy podgotovki po dannym kardiologicheskogo obsledovaniya. Sportivnaya meditsina: nauka i praktika. 2018; 2: 33-6.

29. Moskvin SV, Fedorova TA, Foteeva TS. Plazmaferez i lazernoe osvechivanie krovi. M.-Tver': OOO «Izd-vo «Triada», 2018; 416 p.

30. Grenner D. Gormony, reguliruyushchie metabolizm kal'tsiya. V knige: R Marri, D Grenner et al, redaktory. Biokhimiya cheloveka, tom 2. M.: Mir, 1993; p. 193-204.

31. Bayevsky RM. Cybernetic analysis of heart rate control processes. Actual problems of physiology and pathology of blood circulation. Moscow: Medicine, 1976; 161.

32. Zhemaytite DI. Vegetativnaya reaktsiya sinusovogo uzla serdtsa i zdorovykh i bol'nykh. Analiz serdechnogo ritma. Vil'nyus: Mosklas, 1982; p. 522

33. Bruk TM, Terekhov PA, Osipova NV, Zyukin AV. Effektivnost' vozdeystviya kompleksnogo primeneniya fizicheskikh ergogennykh sredstv na pokazateli spetsial'noy fizicheskoy podgotovlennosti i anaerobnoy rabotosposobnosti vysokokvalifitsirovannykh sportsmenov. Vestnik Rossiyskoy voenno-meditsinskoy akademii. 2019; 1 (65): 113-9.

34. Tambovskiy AN. Sidorenko TA, Yurev YuN, Shurmanov EG. Vliyanie kompleksa fizioterapevticheskikh sredstv na organizm sportsmenov. Uchenye zapiski universiteta imeni PF Lesgafta. 2015; (5): 123.

35. Elizarov NA. Adaptatsionnaya kardioprotektsiya fizicheskimi faktorami v lechenii i profilaktike ishemicheskoy bolezni serdtsa [dissertatsiya]. M., 2007.

36. Eremeeva OV. Physiological features of the effects of biofeedback of brain potentials in athletes with dominance of metabolic heart rate modulator [dissertation]. Arkhangelsk, 2012.

37. Jo H-G, Schmitd S, Inacker E, Markowiak M, Hinterberger Th. Meditation and attention: A controlled study on long-term meditators in behavioral performance and event-related potentials of attentional control. International Journal of Psychophysiology. 2016; 99: 33-9.

38. Muller TA, Shilov SN. Osobennosti urovnya aktivatsii lobnoy kory i neyrometabolizma golovnogo mozga u detey 7-10 let s SDVG. Vestnik Novosibirskogo gosudarstvennogo pedagogicheskogo universiteta. 2017; 7 (5): 193-206.

39. Moskvin SV, Kochetkov AV. Effektivnye metodiki lazernoy terapii. M.-Tver': Triada, 2016; $80 \mathrm{p}$

40. Pavlov SE, Pavlova TN. Tekhnologiya podgotovki sportsmenov. MO, Shchelkovo: Izdatel' Markhotin PYu, 2011; 344 p.

\section{Литература}

1. Анохин П. К. Принципиальные вопросы общей теории функциональных систем. Принципы системной организации функций. М.: Наука, 1973; с. 5-61.

2. Кузнецова Т. Н., Павлов С. Е. Методика применения физиотерапевтических средств (низкоэнергетических ИКлазеров) в тренировочном процессе пловцов. Методическая разработка для преподавателей, аспирантов и студентов РГАФК. М.: РГАФК, 1997; 52 с.

3. Доровских В. А., Бородин Е. А., Бородина Г. П. и др. Влияние низкоэнергетических лазеров на свободнорадикальное окисление глюкозо-6-фосфат дегидрогеназы и каталазь эритроцитов. В сборнике: Материалы Международного конгресса «Лазер и здоровье-99»; Москва, 1999; 435-436.

4. Козель А. И., Попов Г. К. Механизм действия лазерного облучения на тканевом и клеточном уровне. Вестник РАМН. 2000; 2: 41-3.

5. Улащик В. С. Анализ механизмов первичного действия низкоинтенсивного лазерного излучения на организм. Здравоохранение (Минск). 2016; (6): 41-51.

6. Потемкин Л. А. Медико-биологическое обеспечение и квантовая медицина спорта высших достижений. М.: Изд-во ЗАО «МИЛТА-ПКПГИТ», 2001; 135 с.

7. Крупаткин А. И., Сидоров В. В. Функциональная диагностика состояния микроциркуляторно-тканевых систем: Колебания, информация, нелинейность. Руководство для врачей. М.: ЛИБРОКОМ, 2014; 498 с.

8. Богослова Т. В. Влияние низкоинтенсивного лазерного излучения на физическую работоспособность студентов института физической культуры [диссертация]. Ярославль, 2004.

9. Осипова Н. В. Сравнительная характеристика влияния низкоинтенсивного лазерного излучения на уровень физической работоспособности студентов различных специализаций спортивного вуза [диссертация]. СПб., 2008.

10. Прокопюк 3. Н. Устойчивость организма спортсменов к гипоксии и ее коррекция низкоинтенсивным лазерным воздействием [диссертация]. Смоленск, 2010.

11. Лифке М. В. Динамика гормонального статуса спортсменов различной квалификации, выполняющих физическую нагрузку умеренной мощности на фоне лазерного воздействия

[диссертация]. Курск, 2009

12. Волкова А. А. Влияние низкоинтенсивного лазерного излучения на функциональное состояние организма лыжников-гонщиков [диссертация]. Смоленск, 2011.

13. Павлов С. Е., Разумов А. Н., Павлов А. С. Лазерная стимуляция В медико-биологическом обеспечении подготовки квалисиицированных спортсменов. М.: Спорт, 2017; 536 с.

14. Павлов С. Е., Павлов А. С., Петров А. А. Особенности динамики среднегрупповых показателей дисперсионных характеристик функционирования миокарда хоккеистов, использовавших в предстартовой подготовке метод лазерной стимуляции спортивной работоспособности. В сборнике: Олимпийский бюллетень № 15, сост. Мельникова Н. Ю., Трескин А. В., Леонтьева Н. С., Никифорова А. Ю.; М.: Изд-во ЗАО «Олимпийская панорама», 2014; 247-51.

15. Фокин В. Ф., Пономарёва Н. В., Кунцевич Г. И. Электрофизиологические корреляты скорости движения крови по средней мозговой артерии здорового человека. Вестник РАМН. 2013; (10): 57-60

16. Bollinger $\mathrm{A}$. Is high-frequency flux motion due to respiration or to vasomotion activity? In: A. Bollinger et al. Vasomotion and flow motion. Prog. Appl. Microcirculation. Basel, Karger. 1993; 20: 52-58.

17. Fagrell B. Problems using laser Doppler on the skin in clinical practice. Laser Doppler.- London - Los Angeles - Nicosia: Med Orion Publishing Company. 1994; 49-54

18. Федорович А. А. ВЭБ-капилляроскопия - новые возможности мониторирования капиллярного кровотока в коже человека. В сборнике: Материалы XII международной научной конференции «Микроциркуляция и гемореология»; 01-03 июля 2019 г.; Ярославль: Канцлер 2019: 11

19. Murrey RK et al. Harper's Biochemistry. Appleton \& Lange, 1996; $700 \mathrm{p}$.

20. Daniolos A, Lerner AB, Lerner MR. Action of light on frog pigment cells in culture. Pigment Cell Res. 1990; 3 (1): 38-43.

21. Тамбовский А. Н., Сидоренко Т. А. Некоторые результать применения внетренировочного средства в процессе подготовки гребцов. Ученые записки университета имени П.Ф. Лесгафта. 2015; 5 (123): 182-85.

22. Кару Т. Й. Первичные и вторичные клеточные механизмы лазерной терапии. В книге: Москвин С. В., Буйлин В. А., 
редакторы. Низкоинтенсивная лазерная терапия. М.: Техника, 2000; с. 71-94.

23. Мальцев А. П. Механизмы действия лазерного излучения на прокариотические клетки. Международный студенческий научный вестник. 2016; (6): 23.

24. Filippin L, Magalhães PJ, Di Benedetto G et al. Stable interactions between mitochondria and endoplasmic reticulum allow rapid accumulation of calcium in a subpopulation of mitochondria. J Biol Chem. 2003; 278 (40): 39224-34.

25. Schaffer M, Sroka R, Fuchs $\mathrm{C}$ et al. Biomodulative effects induced by $805 \mathrm{~nm}$ laser light irradiation of normal and tumor cells. Journal of Photochemistry and Photobiology B: Biology. 1997; 40 (3): 253-57.

26. Елисеенко В. И. Механизмы взаимодействия низкоэнергетического лазерного излучения ИК-спектра с биологическими тканями В сборнике: Лазеры и аэроионы в медицине под ред. Евстигнеева А. Р., Каплана М. А; КалугаОбнинск, 1997; 71-2.

27. Крупаткин А. И. Неинвазивная оценка тканевого дыхания у человека с использованием вейвлет-анализа колебаний сатурации крови кислородом и кровотока в микрососудах кожи. Физиология человека. 2012; 38 (4): 67-73.

28. Гаврилова Е. А., Ларинцева О. С. Факторы риска внезапной сердечной смерти спортсменов на разных этапах спортивной подготовки по данным кардиологического обследования. Спортивная медицина: наука и практика. 2018; (2): 33-6.

29. Москвин С. В., Федорова Т. А., Фотеева Т. С. Плазмаферез и лазерное освечивание крови. М.-Тверь: ООО «Изд-во «Триада», 2018; 416 с.

30. Греннер Д. Гормоны, регулирующие метаболизм кальция. В книге: Р. Марри, Д Греннер и др., редакторы. Биохимия человека, том 2. М.: Мир, 1993; с. 193-204.

31. Баевский Р. М. Кибернетический анализ процессов управления сердечным ритмом // Актуальные проблемы физиологии и патологии кровообращения. М.: Медицина, 1976; 161 с.
32. Жемайтите Д. И. Вегетативная реакция синусового узла сердца и здоровых и больных. Анализ сердечного ритма. Вильнюс: Москлас,1982; с. 522.

33. Брук Т. М., Терехов П. А., Осипова Н. В., Зюкин А. В. Эффрективность воздействия комплексного применения физических и эргогенных средств на показатели специальной физической подготовленности и анаэробной работоспособности высококвалисицированных спортсменов. Вестник Российской военно-медицинской академии. 2019; 1 (65): 113-9

34. Тамбовский А. Н., Сидоренко Т. А., Юрьев Ю. Н., Шурманов Е. Г. Влияние комплекса фризиотерапевтических средств на организм спортсменов. Ученые записки университета имени П. Ф. Лесгафта. 2015; (5): 123.

35. Елизаров Н. А. Адаптационная кардиопротекция фризическими факторами в лечении и профилактике ишемической болезни сердца [диссертация]. М., 2007.

36. Еремеева О. В. Физиологические особенности эффектов биоуправления потенциалами мозга у спортсменов с доминированием метаболического модулятора сердечного ритма [диссертация]. Архангельск, 2012.

37. Jo H-G, Schmitd S, Inacker E, Markowiak M, Hinterberger Th. Meditation and attention: A controlled study on long-term meditators in behavioral performance and event-related potentials of attentional control. International Journal of Psychophysiology. 2016; (99): 33-9.

38. Муллер Т. А., Шилов С. Н. Особенности уровня активации лобной коры и нейрометаболизма головного мозга у детей 7-10 лет с СДВГ. Вестник Новосибирского государственного педагогического университета. 2017; 7 (5): 193-206.

39. Москвин С. В., Кочетков А. В. Эффективные методики лазерной терапии. М.-Тверь: Триада, 2016; 80 с.

40. Павлов С. Е., Павлова Т. Н. Технология подготовки спортсменов. МО, Щелково: Издатель Мархотин П. Ю., 2011; 344 с. 